J. Clin. Chem. Clin. Biochem.

Vol. 17, 1979, pp. 211-217

\title{
Arginase and Free Amino Acids in Hyperargininemia: Leukocyte Arginine as a Diagnostic Parameter for Heterozygotes
}

By B. Marescau, J. Pintens, A. Lowenthal

Department of Neurochemistry, Born-Bunge Foundation, Universitaire Instelling Antwerpen, Belgium,

\author{
H. G. Terheggen
}

Städt. Kinderkrankenhaus, Köln, Federal Republic of Germany,

and

\section{K. Adriaenssens}

Provincial Institute for Hygiene and Universitaire Instelling Antwerpen, Belgium

(Received September 1/November 21, 1978)

Summary: Arginase activity and free amino acids were measured in plasma, erythrocytes and leukocy tes of patients with hyperargininemia and in controls. There is no arginase activity in the leukocytes and erythrocytes of homozygous patients; in heterozygotes it is normal to low. The activity is 50 to 100 times higher in leukocytes than in erythrocytes. In controls as well as in patients and heterozygotes, the amino acid concentrations are higher in leukocytes than in plasma and erythrocytes. In addition to the increased arginine in the three blood compartments (the result of an arginase deficiency), there is also an obvious decrease of aspartic acid in the ery throcytes of the patients. The arginine concentration in leukocytes of heterozygotes is as high as in homozygotes and can therefore be used as a diagnostic parameter for heterozygotes.

\section{Arginase und freie Aminosäuren bei Hyperargininaemie: Arginin in Leukocyten als diagnostischer Hinweis auf Heterożyote}

Zusammenfassung: Arginase und freie Aminosäuren wưrden in Plasmạ, Erythrocyten und Leukocyten von Patienten mit Hyperargininaemie und Gesunden bestimmt. Arginase ist nicht nachweisbar in den Leukocyten und Erythrocyten homozygoter Patienten; bei heterozygoten ist sie normal bis erniedrigt. Die Aktivität ist 50-100 mal höher in Leukocyten als in Erythrocyten. Bei Gesunden als auch bei Patienten und Heterozygoten sind die Aminosäure-Konzentrationen in den Leukocyten höher als in Plasma und Erythrocyten. Zusätzlich zum erhöhten Arginin in den drei Blutkompartiment auf grund des Arginase-Mangels wurde auch ein klarer Abfall der Asparaginsäure in den Erythrocyten der Patienten gefunden. Die Argininkonzentration in Leukocyten Heterozygoter ist so hoch wie in Homozygoten und kann deshalb als diagnostischer Hinweis auf Heterozygote gewertet werden.

\section{Introduction}

Hyperargininemia was characterised by the determination of amino acid concentrations in biological fluids, and enzyme activities in erythrocytes $(1,2)$. But for a better understanding of the physiology, it is necessary to determine simultaneously free amino acids and arginase (EC
3.5.3.1) in tissues, e.g. in leukocytes, which are easy to separate. We have also determinéd free amino acid concentrations and arginase activity in erythrocytes, in order to acquire a view of the free amino acid distribution in the three blood compartments. This may provide information on amino acid trasport across blood cell membranes, and amino acid metabolism within the blood cells. 
Although many studies have been done on the concentrations of free amino acids in plasma, relatively little is known about their concentrations in blood cells. Soupart (3) and McMenamy et al (4) have reported general studies on the amino acid concentrations in plasma, ery throcytes and leukocytes in normal adults. Studies on plasma and erythrocyte concentrations in normal subjects and adult metabolic patients have been reported by Levy et al (5) and Bhörnesjo et al (6). Quantitative studies on the leukocytes of leukaemic patients and patients with hypoproteinaemia were reported by Lee et al (7) and Gupta et al (8).

It is not easy to compare the values from different authors, owing to the different methods used and the different ways of expressing the results. We have therefore expressed our results in $\mu \mathrm{mol}$ per volume and nmol or $\mu \mathrm{mol}$ per quantity of cells. The amino acid levels also depend on the methods of isolation and washing of the blood cells $(3,9)$.

\section{Materials and Methods}

Venous blood was obtained from 15 controls $^{1}$ ), three sisters affected with hyperargininemia, their heterozygous mother and a heterozygous sister.

\section{Isolation of leukocytes and extraction of amino acids}

About $10 \mathrm{ml}$ heparinzed blood was diluted with $2.5 \mathrm{ml}$ of a $50 \mathrm{~g} / \mathrm{l}$ Dextran 500 solution in $9 \mathrm{~g} / \mathrm{l} \mathrm{NaCl}$. This mixture was allowed to stand for 45 minutes at room temperature. After sedimentation of the red blood cells, the plasma-dextran fraction, which contains the leukocytes, was carefully removed. Two and a half volumes of a $8.7 \mathrm{~g} / 1 \mathrm{NH}_{4} \mathrm{Cl}$ solution were added to this fraction. The samples were placed in a water bath at $37^{\circ} \mathrm{C}$ for 10 minutes, then centrifuged directly at $156 \mathrm{~g}$ for 10 minutes (Martin Christ; Type 03400, Osterode/Harz, W-Germany). The supernatant was deproteinized by adding $50 \mathrm{mg} 5$-sulfosalicylic acid in substance per ml plasma, then used for plasma amino acid determination. The pellet was washed twice with $9 \mathrm{~g} / \mathrm{l} \mathrm{NaCl}$, resuspended in $1 \mathrm{ml} 9 \mathrm{~g} / \mathrm{l} \mathrm{NaCl}$ and then counted with a hemocytometer (W. Schreck, Type: Neubauer, Hofheim, W-Germany). After counting, the cell suspension was lysed by freezing and thawing, and homogenized (Braun, Potter S, Melsungen, W-Germany). The lysed cells were deproteinized by adding $30 \mathrm{mg}$ 5-sulfosalicylic acid in substance and centrifuged (Martin Christ, Type UJ III KS, Osterode/Harz, W-Germany). The supernatant was used for amino acid determinations.

\section{Extraction of amino acids from erythrocytes}

The sedimented ery throcy tes were washed twice with $9 \mathrm{~g} / 1$ $\mathrm{NaCl}$ and counted with a hemocy tometer. The cells were lysed by adding $10 \mathrm{ml}$ distilled water. The hemolysate was deproteinized by adding $130 \mathrm{mg} 5$-sulfosalicylic acid in substance per $\mathrm{ml}$ ery throcyte fraction, and centrifuged. The supernatant was used for amino acid determinations.

1) The controls had no known relationship with individuals carrying abnormalities of the urea cycle.

\section{Amino acid analysis}

The plasma, ery throcy tes and leukocyte supernatan ts from $10 \mathrm{ml}$ blood were lyophilized. The plasma, ery throcy tes and leukocy te amino acids were redissolved in $0.1 \mathrm{~mol} / 1 \mathrm{HCl}$ and placed on an amino acid analyzer (Technicon, Type: AAI, Dublin, Ireland). For amino acid determination in plasma a volume corresponding to $0.5 \mathrm{ml}$ plasma was applied to the column. About $2 \cdot 10^{7}$ leukocytes and $10^{10}$ erythrocytes were used for amino acid analysis. To each sample, $250 \mathrm{nmol}$ norleucine was added as internal standard.

\section{Measurement of arginase activity}

Arginase activity was measured according to the method of Azizi et al (10). The results (tab. 1) are given in $\mu \mathrm{mol}$ of urea produced', by $10^{9}$ cells, per minute at $37^{\circ} \mathrm{C}$ in $0.1 \mathrm{~mol} / 1$ arginine at $\mathrm{pH} 10.14$ (glycine buffer), after activation of the enzyme for $20 \mathrm{~min}$ in $65 \mathrm{mmol} / 1 \mathrm{Mn}^{2+}$ at $55^{\circ} \mathrm{C}$. Urea was measured by the method of Marsh et al (11).

\section{Results}

\section{Arginase activity in blood cells}

In the controls, the arginase activity per cell was 50 to 100 times higher in leukocytes than in erythrocytes (tab. 1). About the same ratio was found between leukocyte and erythrocyte activity in the heterozygotes.

No arginase activity was found in erythrocytes and leukocytes of the patients with hyperargininemia.

The arginase activity in the blood cells of heterozygotes was normal to low.

Tab. 1. Arginase in ery throcy tes and leukocy tes of controls, patients with hyperargininemia (A.W., M.W., I.W.), their heterozygous mother and a heterozygous sister. $\left(\mu \mathrm{mol} / \mathrm{min} \cdot 10^{9} \mathrm{cells}\right)$.

\begin{tabular}{llc}
\hline & Erythrocytes & Leukocy tes \\
\hline Controls & $\left.\left.2.06^{1}\right) \pm 0.548^{2}\right)$ & $\left.134^{1}\right) \pm 49.4^{2}$ ) \\
Heterozygous mother & 1.06 & 93.5 \\
Heterozygous sister & 1.95 & 42 \\
Hyperargininemia (A.W.) & 0 & 0 \\
Hyperargininemia (M.W.) & 0 & 0 \\
Hyperargininemia (I.W.) & 0 & 0
\end{tabular}

1) mean of 15 controls

2) standard deviation

\section{Free amino acids in plasma and blood cells}

Arginine was increased in the plasma of patients with hyperargininemia (tab. 2). Glutamine was also slightly increased. Ornithine and lysine were decreased, while threonine and most of the essential amino acids were decreased only slightly. The other amino acids were near to normal. The plasma arginine and ornithine values of the heterozygotes were intermediate. Glutathione was not detectable in plasma. 
Tab. 2. Free amino acid concentrations in plasma of controls, patients with hyperargininemia (I.W., A.W., M.W.), their heterozygous mother (h.m.) and a heterozygous sister (h.s.). ( $\mu \mathrm{mol} / \mathrm{l})$

\begin{tabular}{|c|c|c|c|c|c|c|c|}
\hline & Controls & & I.W. & A.W. & M.W. & h.m. & h.s. \\
\hline Taurine & $\left.134.9^{1}\right)$ & $\left.\pm 55.7^{2}\right)$ & 73.9 & 121.4 & 108.5 & 129.1 & 143.6 \\
\hline Aspartic acid & 10.7 & $\pm \quad 6.2$ & 12.4 & 11.9 & n.d. $\left.{ }^{3}\right)$ & 4.1 & 7.5 \\
\hline Threonine & 99.1 & $\pm \quad 30.3$ & 57.5 & 44.3 & n.d. $\left.{ }^{3}\right)$ & 94.5 & 102.0 \\
\hline Serine & 110 & \pm 31.8 & 171 & 141.6 & n.d. $\left.{ }^{3}\right)$ & 91.8 & 180.5 \\
\hline Glutamine & 390.7 & \pm 155.3 & 752.3 & 686.6 & n.d. ${ }^{3}$ ) & 450.4 & 286.7 \\
\hline Glutamic acid & 113 & \pm 76.1 & 90.1 & 170.3 & 74 & 98.9 & 79 \\
\hline Proline & 136.5 & \pm 54.2 & 117.3 & 158.6 & 116.7 & 125.6 & 164.8 \\
\hline Citrulline & 22.2 & $\pm \quad 6.2$ & 40.9 & 19.9 & 21.7 & 18.1 & 14.7 \\
\hline Gly cine & 150 & $\pm \quad 47.8$ & 201.5 & 157.5 & 165.1 & 159.9 & 142.8 \\
\hline Alanine & 235.5 & \pm 54.8 & 328 & 261.7 & 289.6 & 235.9 & 243.7 \\
\hline Glutathione & - & - & - & - & - & - & - \\
\hline Valine & 169.4 & \pm 30 & 143.6 & 103.6 & 81.8 & 153.2 & .164 .8 \\
\hline Methionine & 14.9 & $\pm \quad 1.9$ & 18.1 & 32.9 & 15.2 & 15.8 & 17.3 \\
\hline Isoleucine & 54.5 & $\pm \quad 9.7$ & 40.4 & 32.2 & 27.4 & 66.1 & 54.2 \\
\hline Leucine & 101.3 & \pm 18.8 & 57.5 & 44.4 & 41.3 & 102.1 & 94.8 \\
\hline Tyrosine & 36.6 & \pm 5 & 29 & 29.7 & 19 & 42.9 & 42 \\
\hline Phenylalanine & 42.4 & $\pm \quad 5.5$ & 26.7 & 33.4 & 23.7 & 41.7 & 44.7 \\
\hline Ethanolamine & 10.2 & $\pm \quad 3.1$ & 11.1 & 14.6 & 9.4 & 4.8 & 7.8 \\
\hline Ornithine & 61.5 & \pm 10.7 & 36.7 & 35.7 & 34.9 & 54.5 & 50.6 \\
\hline Lysine & 135.4 & \pm 13.8 & 66.6 & 63.3 & 57.7 & 131.2 & 106.3 \\
\hline Histidine & 63.7 & $\pm \quad 8.6$ & 339.8 & 361.1 & 353.2 & 115.9 & 94.5 \\
\hline
\end{tabular}

1) mean of 15 controls

${ }^{2}$ ) standard deviation

3) not determined

Tab. 3. Free amino acid concentrations in ery throcytes of controls, patients with hyperargininemia (l.W., A.W., M.W.), their heterozygous mother (h.m.) and a heterozygous sister (h.s.). ( $\mathrm{nmol} / 10^{9}$ cells)

\begin{tabular}{lcccccrr}
\hline & Controls & & I.W. & A.W. & M.W. & h.m. & h.s. \\
\hline Taurine & $7.98^{1}$ ) & $\pm 4.07^{2}$ ) & 2.45 & 3.37 & 3.27 & 4.10 & 3.92 \\
Aspartic acid & 19.68 & \pm 8.83 & 2.47 & 4.09 & 2.51 & 9.85 & 11.15 \\
Threonine & 7.31 & \pm 2.7 & 4.19 & 2.49 & 2.49 & 6.06 & 5.37 \\
Serine & 12.57 & \pm 3.27 & 14.73 & 11.38 & 13.52 & 10.28 & 12.43 \\
Glutamine & 22.60 & \pm 11.85 & 21.52 & 53.76 & 27.93 & 16.24 & 15.26 \\
Glutamic acid & 23.26 & \pm 9.77 & 32.74 & 23.78 & 22.69 & 21.92 & 15.78 \\
Proline & 10.50 & \pm 2.60 & 7.15 & 5.73 & n.d. & 1.69 & 8.26 \\
Citrulline & 2.11 & \pm 0.48 & 1.92 & 1.45 & 1.68 & 1.23 & 0.88 \\
Glycine & 29.07 & \pm 12.50 & 31.65 & 22.26 & 28.64 & 21.02 & 18.00 \\
Alanine & 30.19 & \pm 7.56 & 32.08 & 26.6 & 39.93 & 19.45 & 20.03 \\
Glutathione & 33.1 & \pm 15.31 & 9.55 & 14.16 & 27.6 & 41.05 & 12.21 \\
Valine & 6.87 & \pm 2.45 & 6.25 & 3.34 & 2.88 & 5.11 & 6.12 \\
Methionine & 0.63 & \pm 0.37 & 0.86 & 0.48 & 0.34 & 0.61 & 0.76 \\
Isoleucine & 1.71 & \pm 0.75 & 1.09 & 0.97 & 0.82 & 1.25 & 1.52 \\
Leucine & 4.2 & \pm 1.73 & 4.19 & 2.08 & 1.8 & 3.35 & 4.37 \\
Tyrosine & 2.65 & \pm 0.86 & 1.86 & 1.34 & 1.04 & 2.38 & 2.15 \\
Phenylalanine & 2.16 & \pm 0.87 & 1.94 & 1.43 & 1.27 & 1.9 & 2.2 \\
Ethanolamine & 1.33 & \pm 0.61 & 1.98 & 0.56 & 1.54 & 0.8 & 1.23 \\
Ornithine & 11.59 & \pm 4.26 & 1.79 & 1.16 & 1.54 & 9.98 & 7.46 \\
Lysine & 11.33 & \pm 4.37 & 5.9 & 3.32 & 3.38 & 8.65 & 7.64 \\
Histidine & 5.85 & \pm 1.17 & 5.6 & 4.88 & 3.73 & 5.11 & 5.26 \\
Arginine & 0.47 & \pm 0.27 & 17.36 & 12.36 & 14.46 & 0.93 & 0.82 \\
\hline
\end{tabular}

\footnotetext{
1) mean of 15 controls

2) standard deviation

3) not determined
}

The levels of arginine in ery throcytes (tab. 3) were higher in the patients than in the controls and heterozygotes. Aspartic acid, ornithine and lysine were decreased, threonine only slightly. Glutathione was present in high concentrations.

In leukocytes (tab. 4), the concentration of arginine was higher in patients and heterozygotes than in controls. However, the ornithine level was normal.
Table 5 makes a comparison of the plasma ery throcyte concentrations in controls and in hyperargininemia. In the controls we observed much higher concentrations of aspartic acid and glutathione in the erythrocytes. Arginine and most of the essential amino acids were less concentrated in erythrocytes. The concentration of the other amino acids was more or less similar in plasma and ery throcytes. The pattern was similar in the patients with hyperargininemia, except for aspartic acid and 
Tab. 4. Free amino acid concentrations in leukocytes of controls, patients with hyperargininemia (I.W., A.W., M.W.), their heterozygous mother (h.m.) and a heterozygous sister (h.s.). ( $\mu \mathrm{mol} / 10^{9}$ cells)

\begin{tabular}{|c|c|c|c|c|c|c|c|c|c|}
\hline \multirow{7}{*}{$\begin{array}{l}\text { Taurine } \\
\text { Aspartic acid } \\
\text { Threonine } \\
\text { Serine } \\
\text { Glutamine } \\
\text { Glutamic acid }\end{array}$} & \multicolumn{2}{|c|}{ Controls (our results) } & \multirow{2}{*}{$\frac{\text { I.W. }}{10.88}$} & \multirow{2}{*}{$\frac{\text { A.W. }}{13.85}$} & \multirow{2}{*}{$\frac{M . W .}{11.02}$} & \multirow{2}{*}{$\frac{\text { h.m. }}{16.93}$} & \multirow{2}{*}{$\frac{\text { h.s. }}{15.90}$} & \multicolumn{2}{|c|}{ Controls (Houpert (19)) } \\
\hline & $\left.15.56^{1}\right)$ & $\left.\pm 4.36^{2}\right)$ & & & & & & $\left.9.06^{1}\right)$ & $\left.\pm 1.80^{2}\right)$ \\
\hline & 1.19 & \pm 0.35 & 2.43 & 2.94 & 1.87 & 2.63 & 2.48 & 1.40 & \pm 0.33 \\
\hline & 0.56 & \pm 0.16 & 1.33 & 2.08 & 1.27 & 1.90 & 1.50 & 1.48 & \pm 0.53 \\
\hline & 0.92 & \pm 0.34 & 2.34 & 3.67 & 2.24 & 2.53 & 2.39 & 1.90 & \pm 0.82 \\
\hline & 0.74 & \pm 0.28 & 1.64 & 1.93 & 1.51 & 2.09 & 1.70 & 1.44 & \pm 0.48 \\
\hline & d 1.86 & \pm 0.72 & 3.97 & 4.97 & 3.43 & 4.4 & 3.84 & 2.40 & \pm 0.73 \\
\hline Proline & traces & - & .1 .22 & 1.37 & 0.84 & 1.54 & 1.25 & n.d. $\left.{ }^{3}\right)$ & - \\
\hline Citrulline & traces & - & traces & traces & traces & traces & traces & 0.88 & \pm 0.29 \\
\hline Gly cine & 1.04 & \pm 0.32 & 2.64 & 3.08 & 2.24 & 2.42 & 2.15 & 2.04 & \pm 0.89 \\
\hline Glutathione & 0.40 & \pm 0.11 & 0.11 & 0.12 & 0.11 & 0.20 & 0.12 & in.d. & - \\
\hline Valine & 0.67 & \pm 0.18 & 1.68 & 2.49 & 1.63 & 2.38 & 2.06 & 1.71 & \pm 0.75 \\
\hline Methionine & 0.28 & \pm 0.10 & 0.74 & 1.11 & 0.82 & 1.28 & 1.00 & 0.85 & \pm 0.37 \\
\hline Isoleucine & 0.45 & \pm 0.19 & 1.34 & 2.19 & 1.31 & 2.10 & 1.67 & 1.19 & \pm 0.64 \\
\hline Leucine & 1.29 & \pm 0.41 & 2.86 & 4.14 & 2.80 & 3.68 & 3.30 & 3.59 & \pm 1.43 \\
\hline Tyrosine & 0.34 & \pm 0.13 & 0.99 & 1.48 & 1.01 & 1.47 & 1.21 & 0.91 & \pm 0.41 \\
\hline Phenylalanine & 0.61 & \pm 0.21 & 1.36 & 1.86 & 1.34 & 2.20 & 1.60 & 1.14 & \pm 0.52 \\
\hline Ethanolamine & 0.48 & \pm 0.18 & 0.76 & 0.65 & 0.62 & 0.55 & 0.45 & n.d. ${ }^{3}$ ) & - \\
\hline Ornithine & 0.41 & \pm 0.23 & 0.29 & 0.54 & 0.44 & 0.48 & 0.34 & 0.27 & \pm 0.12 \\
\hline Lysine & 0.70 & \pm 0.21 & 1.76 & 2.24 & 1.44 & 1.84 & 1.74 & 3.53 & \pm 0.80 \\
\hline Histidine & 0.22 & \pm 0.11 & 0.57 & 0.83 & 0.62 & 0.67 & 0.68 & 0.60 & \pm 0.29 \\
\hline Arginine & 0.38 & \pm 0.18 & 1.83 & 2.21 & 1.74 & 1.68 & 1.54 & traces & - \\
\hline
\end{tabular}

1) mean of 15 controls

2) standard deviation
3) not determined

Tab. 5. Plasma/ery throcy te ratio in controls, patients with hyperargininemia (I.W., A. W., M. W.), their heterozygous mother (h.m.) and a heterozygous sister (h.s.).

\begin{tabular}{|c|c|c|c|c|c|c|c|}
\hline & Controls & & I.W. & A.W. & M.W. & h.m. & h.s. \\
\hline Taurine & $\left.1.71^{1}\right)$ & $\pm 0.73^{2}$ ) & 2.62 & 3.13 & 2.88 & 2.74 & 3.19 \\
\hline Aspartic acid & 0.06 & \pm 0.05 & 0.44 & 0.25 & n.d. $\left.{ }^{3}\right)$ & 0.04 & 0.06 \\
\hline Threonine & 1.26 & \pm 0.48 & 1.2 & 1.55 & n.d. $\left.{ }^{3}\right)$ & 1.36 & 1.65 \\
\hline Serine & 0.80 & \pm 0.32 & 1.01 & 1.08 & n.d. ${ }^{3}$ ) & 0.78 & 1.26 \\
\hline Glutamine & 1.78 & \pm 0.80 & 3.04 & 1.11 & n.d. $\left.{ }^{3}\right)$ & 2.41 & 1.63 \\
\hline Glutamic acid & 0.47 & \pm 0.26 & 0.24 & 0.62 & 0.28 & 0.39 & 0.43 \\
\hline Proline & 1.04 & \pm 0.25 & 1.43 & 2.41 & - & 1.42 & 1.74 \\
\hline Citrulline & 0.81 & \pm 0.33 & 1.85 & 1.67 & 1.12 & 1.28 & 1.45 \\
\hline Glycine & 0.51 & \pm 0.25 & 0.55 & 0.62 & 0.50 & 0.66 & 0.69 \\
\hline Alanine & 0.69 & \pm 0.20 & 0.89 & 0.85 & 0.65 & 1.05 & 1.06 \\
\hline Glutathione & - & - & - & - & - & - & - \\
\hline Valine & 2.49 & \pm 1.18 & 2 & 2.7 & 2.47 & 2.61 & 2.34 \\
\hline Methionine & 2.69 & \pm 2.4 & 1.82 & 5.98 & 3.89 & 2.25 & 1.99 \\
\hline Isoleucine & 3.26 & \pm 1.47 & 3.23 & 2.99 & 2.91 & 4.59 & 3.10 \\
\hline Leucine & 2.48 & \pm 1.28 & 1.19 & 1.86 & 1.99 & 2.65 & 1.88 \\
\hline Tyrosine & 1.33 & \pm 0.47 & 1.35 & 1.92 & 1.60 & 1.57 & 1.70 \\
\hline Phenylalanine & 2.02 & \pm 0.99 & 1.20 & 2.04 & 1.62 & 1.91 & 1.76 \\
\hline Ethanolamine & 0.72 & \pm 0.32 & 0.48 & 2.28 & 0.53 & 0.52 & 0.55 \\
\hline Ornithine & 0.52 & \pm 0.21 & 1.78 & 2.68 & 1.97 & 0.47 & 0.59 \\
\hline Lysine & 1.12 & \pm 0.40 & 0.99 & 1.66 & 1.49 & 1.32 & 1.24 \\
\hline Histidine & 1.00 & \pm 0.33 & 1.17 & 1.64 & 1.41 & 1.14 & 1.20 \\
\hline Arginine & 20.21 & \pm 15.79 & 1.70 & 2.54 & 2.12 & 10.05 & 10.83 \\
\hline
\end{tabular}

1) mean of 15 controls

2) standard deviation

3) not determined

arginine. The plasma/erythrocy te ratio in hyperargininemia was much higher for aspartic acid and lower for arginine than in the controls.

Table 6 gives a comparison of the amino acid concentration in plasma, ery throcytes and leukocytes of . controls. The values are expressed in $\mu \mathrm{mol}$ per litre plasma, litre ery throcytes and litre leukocytes. They are obtained by taking the values of table 2 and table 3 , and by taking the mean erythrocytes volume as $87 \mathrm{fl}$. The mean granulocy te volume was taken as $1022 \mathrm{fl}$. For the lymphocyte and monocyte volumes, we used $1221 \mathrm{fl}$ and $2145 \mathrm{fl}$ respectively. Our isolation procedure yielded the following fractions: 0.86 granulocytes, 0.12 lymphocytes and 0.02 monocytes. 
Tab. 6. Free amino acid concentrations in plasma, ery throcytes and leukocy tes of controls. ( $\mu \mathrm{mol} / \mathrm{l})$

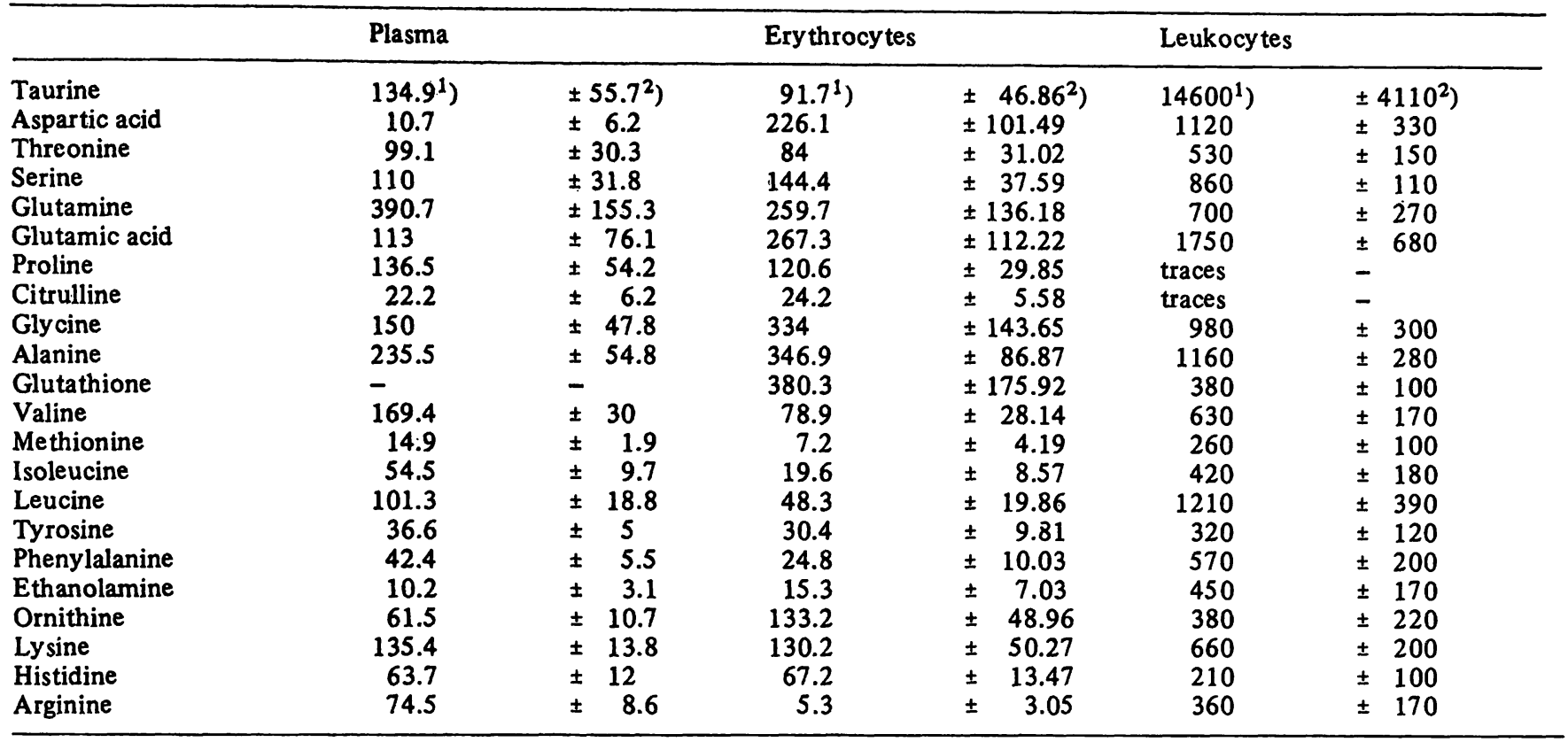

1) mean of 15 controls

2) standard deviation

Tab. 7. Total free amino acid distribution between plasma, erythrocy tes and leukocy tes $(\mu \mathrm{mol})$.

\begin{tabular}{|c|c|c|c|c|c|c|}
\hline \multirow[b]{2}{*}{ Taurine } & \multicolumn{2}{|l|}{ Plasma $^{3}$ ) } & \multicolumn{2}{|c|}{ Erythrocy tes ${ }^{3}$ ) } & \multicolumn{2}{|c|}{ Leukocytes ${ }^{3}$ ) } \\
\hline & $\left.405^{1}\right)$ & $\pm 167^{2}$ ) & $275^{1}$ & $\pm 140^{2}$ ) & $\left.876^{1}\right)$ & $\left.\pm 246^{2}\right)$ \\
\hline Aspartic acid & 32 & \pm 19 & 678 & \pm 315 & 67 & \pm 20 \\
\hline Threonine & 297 & \pm 91 & 252 & \pm 93 & 32 & \pm 9 \\
\hline Serine & 330 & \pm 96 & 433 & \pm 113 & 52 & \pm 7 \\
\hline Glutamine & 1172 & \pm 466 & 779 & \pm 408 & 42 & \pm 16 - \\
\hline Glutamic acid & 339 & \pm 228 & 802 & \pm 337 & 105 & \pm 41 \\
\hline Proline & 410 & \pm 167 & 362 & \pm 89 & traces & - \\
\hline Citrulline & 67 & \pm 19 & 73 & \pm 17 & traces & - \\
\hline Gly cine & 450 & \pm 144 & 1002 & \pm 431 & 59 & \pm 18 \\
\hline Alanine & 707 & \pm 165 & 1041 & \pm 260 & 70 & \pm 17 \\
\hline Glutathione & - & - & 1141 & \pm 528 & 23 & \pm 6 \\
\hline Valine & 508 & \pm 90 & 237 & \pm 84 & 38 & \pm 10 \\
\hline Methionine & 45 & \pm 8 & 22 & \pm 13 & 16 & \pm 6 \\
\hline Isoleucine & 164 & \pm 29 & 59 & \pm 26 & 25 & \pm 11 \\
\hline Leucine & 304 & \pm 56 & 145 & \pm 59 & 73 & \pm 23 \\
\hline Tyrosine & 110 & \pm 15 & 91 & \pm 29 & 19 & \pm 7 \\
\hline Phenylalanine & 127 & \pm 16 & 74 & \pm 30 & 34 & \pm 12 \\
\hline Ethanolamine & 31 & \pm 9 & 46 & \pm 21 & 27 & \pm 10 \\
\hline Ornithine & 185 & \pm 32 & 400 & \pm 147 & 23 & \pm 13 \\
\hline Lysine & 406 & \pm 41 & 391 & \pm 151 & 40 & \pm 12 \\
\hline Histidine & 201 & $\pm \quad 37$ & 202 & \pm 40 & 13 & \pm 6 \\
\hline Arginine & 222 & \pm 26 & 16 & \pm 9 & 22 & \pm 10 \\
\hline
\end{tabular}

1) mean of 15 controls

2) standard deviation

3) calculated for a theoretical whole blood volume of 61 , plasma volume of 31 , ery throcy tes volume of 31 and leukocy tes volume of $60 \mathrm{ml}$.

Table 7 gives the distribution of the free amino acids between the three blood compartments of the whole blood reservoir in the controls. The values are calculated by assuming the total mean blood volume to be 6 litres, the plasma volume to be 3 litres, the ery throcyte volume to be 3 litres, and the leukocytes volume to be $60 \mathrm{ml}$.

\section{Discussion}

There is no arginase activity in the blood cells of patients with hyperargininemia. In the blood cells of heterozygotes, the activity is normal to low. The determination of the enzyme activity in erythrocytes and leukocytes could therefore only be used as a diagnostic parameter 
for homozygous patients, and not for heterozygotes. The arginase activity in erythrocytes of heterozygotes seems high enough to keep the arginine concentration at a normal level; but this is not the case in the leukocytes. The arginine concentration in the leukocytes of heterozygotes is as high as in homozygotes. This could be used as a diagnostic parameter for heterozygous arginase deficiency, providing this observation can be confirmed in heterozygotes of other patients with hyperargininemia, independent of the heterogeneity observed in the homozygous patients. For example, hyperammonemia of ten is a diagnostic parameter for homozygous patients, but three hyperargininemia patients did not show hyperammonemia $(12,13,14)$ at the time of diagnosis. Probably they showed periods of hyperammonemia when they were younger.

Before interpreting the amino acid concentration values we had to take into account the influence of washing the blood cells with saline. As observed by Soupart (3), some amino acids are lost into the saline washing medium. This loss could explain the deviation of the plasma/erythrocyte ratio from unity for some essential amino acids, such as valine, methionine, isoleucine, leucine and phenylalanine (tab. 5). Taking this fact into account, we see that the concentration of most of the amino acids is more or less similar in plasma and erythrocytes, both in controls, and in the patients with hyperargininemia.

However, glutathione and aspartic acid showed much higher concentrations in the erythrocytes of the controls In the erythrocytes of hyperargininemia, only glutathione shows a much higher concentration in comparison with the plasma. The plasma/erythrocyte ratio for aspartic acid in patients with hyperargininemia is much higher. The high concentration of aspartic acid in erythrocytes of the controls could be explained by intracellular "trapping", by intracellular deamination of aspargine or by glutamic-oxalacetic transaminase systems $(3,5)$. Normally, aspartic acid plays an important role in the regulation of the urea cycle. Mitochondrial aspartic acid is an inhibitor of carbamyl phosphate synthetase (15). In cytoplasm, aspartic acid is used as cosubstrate of arginino-succinate synthetase, and in the pyrimidine synthesis. It is also used in the biosynthesis of guanidinosuccinic acid (16). The reason why the aspartic acid values in ery throcytes of patients with hyperargininemia fall to the plasma values is not yet clear.

The relatively high concentration of glutathione in erythrocytes is associated with the maintainance of haemoglobin in its native, soluble form. Glutathione could also play a role in the membrane transport of amino acids (17).

A third group of amino acids, arginine and most of the essential amino acids, is less concentrated in erythrocytes than in plasma. The plasma/erythrocyte ratio for arginine is therefore higher than unity. One must keep in mind that this ratio depends on the time taken to separate the erythrocytes from the whole blood, i.e. it depends on the time during which arginase might. further catabolize arginine in the erythrocytes.

In the controls and in hyperargininemia, the amino acid concentrations are higher in leukocytes than in the plasma and ery throcytes (tab. 6). This was to be expected, since leukocytes are living cells, and it is known that cells have much higher amino acid concentrations than blood plasma (18). Taurine represents $50 \%$ of the total free amino acid pool in leukocytes. Table 7 gives us a better understanding of the distribution of the free amino acids between the three blood compartments of the whole blood reservoir.

When comparing the concentrations of free amino acids in leukocytes of patients with hyperargininemia and controls, the following points should be noted: our controls are males, while the three patients with hyperargininemia, the heterozygous mother and a heterozygous sister are females. Houpert (19) found that all the amino acids, except taurine and ornithine, were more concentrated in the leukocytes of women (tab. 4). In fact only arginine is increased in the leukocytes of the patients and heterozygotes. The other amino acids, including ornithine, are quite normal.

\section{Acknowledgements}

The authors wish to thank Mr. J. Caers for his technical assistance. This investigation was supported by grants from the Nationaal Fonds voor Geneeskundig We tenschappelijk Oriderzoek, the Instituut ter bevordering van Wetenschappelijk Onderżoek in de Nijverheid en de Landbouw, the Ministerie van Nationale Opvoeding, the Vrije Universiteit Brussel and the Universitaire Instelling Antwerpen. 


\section{References}

1. Terheggen, H. G., Schwenk, A., Lowenthal, A., Van Sande, M. \& Colombo, J. P. (1970), Z. Kinderheilkd. 107, 313323.

2. Adriaenssens, K., Karcher, D., Lowenthal, A. \& Terheggen, H. G. (1976), Clin. Chem. 22, 323-326.

3. Soupart, P. (1962) in Amino Acid Pools (Holden, J. T., ed.), Elsevier Publishing Company, Amsterdam, pp. 220262.

4. McMenamy, R. H., Lund, C. C., Neville, G. J. \& Wallach, D. F. H. (1960), J. Clin. Invest. 29, 1675-1687.

5. Levy, H. L. \& Barkin, E. (1971), J. Lab. Clin. Med. 78, 517-523.

6. Björnesjö, K. B. (1968), Clin. Chim. Acta 20, 17-22.

7. Lee, M. B., Bolger, D. \& Bridges, J. M. (1969), Acta Haematol. 42, 86-93.

8. Gupta, M. \& Agarwal, K. N. (1973), Br. J. Nutr. 29, 151157.

9. Wolfrom, G. W. \& Asplund, J. M. (1976), Clin. Biochem. 9, 180-183.
10. Azizi, E., Dror, Y. \& Wallis, K. (1970), Clin. Chim. Acta 28 , 391.

11. Marsh, W. H., Fingerhut, B. \& Miller, H. (1965), Clin. Chim. Acta 11, 614 .

12. Cederbaum, S. D., Shaw, K. N. F. \& Valente, M. (1977), J. Pediatr. 90, 569-573.

13. Snyderman, S. E., Sansaricq, C., Chen, W. J., Norton, P. M. \& Phansalkar, S. V. (1977), J. Pediatr. 90, 563-568.

14. Michels, V. V. \& Beaudet, A. L. (1977), Pediatr. Res. 11, 460.

15. Rajiman, L. (1976) in Urea Cycle (Grisolia, S., Baguena, R. \& Mayor, F., eds.) Wilsey, S., N.Y. p. 243.

16. Perez, G., Rey, A. \& Schiff, E. (1976), J. Clin. Invest. 57, 807-809.

17. Meister, A. (1973), Science 180, 33-39.

18. Tallan, H. H., Moore, S. \& Stein, W. H. (1954), J. Biol. Chem. 211, 927.

19. Houpert, Y., Tarallo, P. \& Siest, G. (1976), Clin. Chim. Acta 69, 383-386.
B. Marescau,

Dept. Neurochemistry,

Geneeskunde II,

Universitaire Instelling Antwerpen,

Universiteitsplein 1,

B-2610 Wilrijk. 


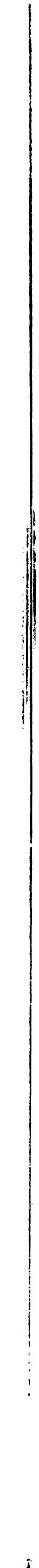

